\title{
The political consequences of the product cycle: industrial history and political outcomes
}

James R. Kurth

\section{The public policies of major industries: the contemporary conflict}

What explains the continuing stagnation in the industrial economies of the West? What will be the impact of such stagnation upon domestic politics and upon international relations? Are there domestic and foreign policies which the state can undertake to bring about a return to sustained economic prosperity and a recapitulation of that lost golden age of 1948-1973? These are now the central questions for scholars in the emerging field of international political economy. A recent special issue of International Organization, edited by Peter Katzenstein, has presented some of the most useful and sophisticated approaches to these questions and analyses of the international political economy of the West during the period of the last thirty years. ${ }^{1}$

These questions are, of course, also the central ones for major economic actors such as industrial corporations and financial institutions. And here we can distinguish five different answers or solutions to the problem of economic

The preparation of this article was facilitated by a year spent at the Institute for Advanced Study, Princeton, New Jersey, and by discussions there with Albert Hirschman. I have also benefited from comments by Thomas Ferguson, Peter Gourevitch, and Martin Shefter.

${ }^{1}$ Peter J. Katzenstein, editor, Between Power and Plenty: Foreign Economic Policies of Advanced Industrial States, a special issue of International Organization 31, 4 (Autumn 1977). A systematic and perceptive review of recent literature on one theme of the new international political economy, the impact of international economics upon domestic politics, is given in Peter Gourevitch, "The Second Image Reversed: The International Sources of Domestic Politics," International Organization 32, 4 (Autumn 1978).

International Organization 33,1, Winter 1979

0020-8183/79/0001-0001 $\$ 01.00 / 0$

(c) 1979 by the Board of Regents of the University of Wisconsin System 
stagnation. Each is preferred and supported by a particular cluster of industries or banks, and each has particular implications for domestic and foreign policies.

The most minimal solution to economic stagnation, in the sense that it requires the least change from government policies of recent years, is the conventional Keynesian one of government-induced demand-creation. This approach is preferred by the consumer-durables industries, the most important of which is the automobile industry. A familiar variation is government spending on weapons procurement and government support of weapons exports; this approach of mutant or military Keynesianism is preferred by the aerospace industry. The two variations on a Keynesian theme, supported by the two leading industries of the long prosperity of 1948-1973 which contributed so much to the acceptance of Keynes' ideas, in turn favor the continuation of the existing system of international free trade. Unfortunately, however, these two Keynesian approaches to economic stagnation are so minimal that they are already perceived by other economic sectors as inadequate for their needs.

A third approach requires greater change from past priorities: systematic restraint or reduction of industrial wages and welfare benefits, in order to increase the rate of profit and thus the amount of capital available for reinvestment in industry to make it more competitive in the world market. This approach, once known as deflation and now often associated with the ideas of Milton Friedman, is preferred by the large commercial banks heavily engaged in international operations. And, of course, this approach also favors the continuation of the existing system of international free trade.

The fourth approach would be rather more radical: it would displace the system of international free trade with one of "organized free trade," i.e., international cartels, or even with one of vigorous protection of national industries with tariffs and quotas against imports. This, its advocates claim, would permit sufficient capital formation to make the protected industries efficient once again. This approach, which has been called neomercantilism, is of course the one preferred by the oldest industries, in particular the textile, steel, and chemical industries of Europe and America.

The above four solutions focus on preservation of existing industries. A fifth, rather different approach is possible, which focuses on the creation of new industries or indeed new leading sectors whose rapid growth would lift up the entire economy behind them, much as the automobile industry did in America in the 1920s and in Europe in the 1950s-1960s. And since the nation which introduces a new industry has a natural advantage in the world market for a decade or even for a generation, industrial innovation would also favor the continuation of the system of international free trade. This approach draws upon that other great economist of the 1930s, Joseph Schumpeter, who saw the advantages of "gales of creative destruction," i.e. depressions, which pruned the economy of overinvestment in old industries and cleared the way for investment in new ones, but whose ideas were eclipsed by Keynes' during 
the long prosperity of $1948-1973 .{ }^{2}$ By its nature, its advocates would be found among new, growing industries, such as telecommunications, rather than mature, established ones, and among investment banks, rather than commercial ones.

The politics of the next few years, then, will involve the conflict between these alternative solutions to economic stagnation and the conflict between the different industries that support them. But it will not be the first time that politics in major industrial countries have been shaped by the public policies of major industries and by the conflicts between them.

This essay seeks to add a historical dimension to the analysis of the political impact of different industries. It examines the political tendencies of three successive leading sectors in Europe and America over the last two centuries-textiles, steel, and automobiles. Each of these has been the largest industry for several major industrial nations in the West at one time or another. Of course, there have been other industries which have also formed major economic sectors in particular countries at particular times, for example, the chemical and electrical industries in Germany, which we will also discuss, and the aerospace industry in the United States. Nevertheless, from the overall perspective of comparative economic history, the textile, steel, and automobile industries assume an especially prominent place.

Each of these three industries has gone through what could be seen as a life cycle of growth, stagnation or saturation, and decline in the major countries of Europe and in the United States. The process has been similar to one which Raymond Vernon has analyzed in his studies of contemporary transnational enterprises and which he has termed the product cycle. ${ }^{3}$ In Vernon's concept the product cycle consists of four phases:

1. Innovation of a product and growth of its sales in the domestic market.

2. Saturation of the domestic market and export of the product to foreign markets. Exports will go first to those countries whose demand structures (e.g., national income per capita) are most similar to that in the home country. When these markets in turn are saturated, the export drive will move on to countries whose demand structures are less similar.

3. Manufacture of the product within foreign markets, i.e., direct foreign investment. Again, investment will go first to those countries

\footnotetext{
${ }^{2}$ Joseph A. Schumpeter, Business Cycles: A Theoretical, Historical, and Statistical Analysis of the Capitalist Process, two volumes (New York: McGraw-Hill, 1939).

${ }^{3}$ Raymond Vernon, Sovereignty at Bay: The Multinational Spread of U.S. Enterprises (New York: Basic Books, 1971). An earlier formulation of the idea of certain patterns or cycles in the development of industries can be found in Walther G. Hoffmann, The Growth of Industrial Economies, translated by W. O. Henderson and W. H. Chaloner (Manchester: Manchester University Press, 1958).
} 
whose supply structures (e.g., factors of production) and demand structures are most similar to those in the home country and later to countries whose supply structures are less similar. Within the home country, the manufacture of the product reaches a plateau.

4. Export of the product from foreign countries into the original home market. Eventually, indeed, there will be export of the product from the latest foreign countries to manufacture it into not only the original home market but also into other foreign countries which had once been the latest manufacturers. Within the home country and these other earlier producers, the manufacture of the product goes into decline.

These four phases describe very well the life cycle of the automobile industry in the United States and in the countries in Western Europe. But the life cycles of the textile industry and the steel industry have also been variations on the same theme. The textile and steel industries rarely engaged in direct foreign investment in manufacturing, phase 3, but each passed through the other three phases. And in the steel industry there was the functional equivalent of phase 3 with indirect foreign investment, the financing of the foreign railroads which were the major final consumer of the home steel industry. In addition, as we shall see, the steel industry passed through its own peculiar phase, that of government procurement of its products for military purposes.

In his own work, Vernon has not extensively examined the consequences of the product cycle for major political outcomes. However, Robert Gilpin, in a major, pathbreaking book, has drawn on the concept of the product cycle, expanded it into the concept of the growth and decline of entire national economies, and analyzed the relations between this economic cycle, national power, and international politics. ${ }^{4}$

In this essay, we will pursue these themes of Vernon and Gilpin by examining some of the political consequences of the industrial life cycles of textiles, steel, and automobiles over the last two centuries. In general, the major consequences of the domestic growth phase of an industry have been for domestic politics, including the nature of political regimes. Conversely, the major consequences of the later phases, those of foreign exports and foreign investments, have been for foreign policies. For the textile industry and the steel industry, our focus will be on the major countries of Europe; for the automobile industry, we will widen our focus to include the United States.

Of course, many of the political outcomes that we will discuss have been enormously complex in their causes and can hardly be adequately explained by industrial factors alone. The rise of the liberal state in the nineteenth century, the "new imperialism" of the 1870s-1890s, the Anglo-German naval race

\footnotetext{
${ }^{4}$ Robert Gilpin, U.S. Power and the Multinational Corporation: The Political Economy of Foreign Direct Investment (New York: Basic Books, 1975).
} 
before World War I, the coming to power of Hitler in 1933, and the political stability of Western democracies in the thirty years after World War II-these momentous events have each been the subject of an enormous and sophisticated historical literature, rich in an array of competing explanations, and many readers will disagree with the particular interpretation offered here. We make no claim that our analysis provides a full explanation and understanding of these historical phenomena. It is our suggestion, however, that the industrial factor has a consistency over time and a commonality over space that gives it a special value as an explanatory approach.

\section{The political tendency of the textile industry}

\section{The domestic growth phase}

In almost all countries, the first stage in industrialization has been the creation of a textile industry. This has required the mobilization of relatively modest amounts of capital, modest, that is, in relation to the amount of capital already available in the country as a result of pre-industrial enterprises and also modest in relation to the amount of capital that has been needed for the creation of later industries, such as steel, railroads, chemicals, automobiles, and aerospace. Consequently, the textile industries of Europe (and also of the United States and the most advanced countries of Latin America) were created for the most part by family firms, and the industries grew through the reinvestment of their earnings. In contrast with later industries, the capital accumulation for textile industrialization could be accomplished largely without dependence upon financing from banks, the state, or foreign investors. ${ }^{5}$

The lack of dependence upon financing from banks had important consequences for the development of financial institutions. The financial agencies that grew up around the textile industry were clearing houses and commercial banks engaged in short-term credits to merchants. They were not investment houses and industrial banks engaged in long-term credits to industry. Those banks that did engage in long-term credits at the time did so with loans to governments, not to industries.

\footnotetext{
${ }^{5}$ E. J. Hobsbawm, The Age of Revolution: Europe 1789-1848 (London: Weidenfeld and Nicolson, 1962); also the country studies in Carlo M. Cipolla, editor, The Emergence of Industrial Societies (London: Collins, Fortana Books, 1973). Statistics on the growth of the textile industry in European countries can be found in B. R. Mitchell, European Historical Statistics, 1750-1970 (New York: Columbia University Press, 1976), pp. 427-436; and in Cipolla, op. cit., pp. 780-788. Three useful overall accounts of European industrialization, from contrasting perspectives, are David S. Landes, The Unbound Prometheus: Technological Change and Industrial Development in Western Europe from 1750 to the Present (Cambridge: Cambridge University Press, 1969); Tom Kemp, Industrialization in Nineteenth Century Europe (London: Longman, 1969); and W. W. Rostow, The Stages of Economic Growth (Cambridge: Cambridge University Press, 1960; second edition, 1971), elaborated in his The World Economy: History and Prospect (Austin: University of Texas Press, 1978). In his works, Rostow develops and employs at length the concepts of the leading sector.
} 
The lack of dependence of the textile industry upon financing from the state also had important consequences for the development of political institutions. The capital accumulation for textile industrialization could be accomplished largely without state intervention, except for the elimination of barriers to a free market within the national boundaries (e.g., internal tariffs) and for the erection of external tariffs on occasion for the protection of the "infant industry." Textile manufacturers did not want the dynastic-authoritarian state of the past, and they did not need the technocratic-authoritarian state of the future. Rather, the textile manufacturers in Europe in the first half of the nineteenth century were opposed to many of the traditional activities of the state. They did not want the internal tariffs, the consumer taxes, and the tedious regulations of the absolutist monarchies, which prevented the manufacturers from selling their goods in a nationwide market. And they did not want the local guild monopolies and local welfare systems, which also prevented them from drawing their labor from a nationwide market. ${ }^{6}$ Similarly, the commercial banks wanted an end to restrictions on the free movement of capital. To systematically eliminate the traditional impediments to free movement of goods, labor, and capital, however, the textile manufacturers and commercial bankers needed institutionalized representation at the national center of power. To achieve this they needed "the supremacy of parliament," ideally within "the liberal state." But the textile manufacturers did not need the assistance of the state to mobilize large amounts of investment capital; nor did they yet need its assistance to demobilize large numbers of socialist workers, services that would later be performed by such diverse authoritarian governments as those of Napoleon III in France, Bismarck in Germany, Mussolini in Italy, and Primo de Rivera and Franco in Spain.

The liberal state, with parliamentary supremacy and with property suffrage, was the most finely-tuned solution to the problems of the textile industry (and of other industries producing light consumer goods such as shoes) and of commercial banking. The liberal state gave them the abolition of traditional barriers to trade; parliamentary supremacy meant that they would be represented at the center of national power; and property suffrage meant that only they and the traditional elites would be so represented. As such, there was, in the familiar phrase of Max Weber (and of Goethe before him), an "elective affinity" between the textile industry, commercial banking, and such a regime. The political theory of the coalition between the textile industry and commercial banking was summed up by Thomas Macaulay in 1830:

Our rulers will best promote the improvement of the nation by confining themselves strictly to their legitimate duties, by leaving capital to find its most lucrative course, commodities their fair price, industry and intelligence their national reward, idleness and folly their natural punish-

\footnotetext{
${ }^{6}$ Frederick B. Artz, Reaction and Revolution, 1814-1832 (New York: Harper and Row, 1963), chapters I-III; Hobsbawm, op. cit., chapter 2.
} 
ment, by maintaining peace, by defending property, by diminishing the price of law, and by observing strict economy in every department of the state. Let the government do this, the people will do the rest. ${ }^{7}$

We should not overemphasize the actual consequences of this elective affinity between textiles and liberals, however, for in Europe the political impact of the textile industry varied from one country to another according to when the country industrialized and to how the industry fit into the international market.

\section{The British model}

The connection between textile industrialization and the liberal institutions was most obvious in the first industrializer, Britain, which in the early nineteenth century was simultaneously "the workshop of the world," "the mother of parliaments," and the center of "Manchester liberalism."8 The textile industry also had a major political impact in the second wave of industrializers, that is, France, Belgium, and Switzerland, each of which experienced rapid growth in the industry in the $1820 \mathrm{~s}$. The textile manufacturers were a major force in the Revolutions of 1830 in each of these three countries (as they were in the related conflict over the Great Reform Bill in Britain in 1830-1832). And they were a major force in the establishment and support of the succeeding liberal regimes: the Orleanist Monarchy in France (the "Bourgeois Monarchy" or monarchie censitaire), the new and similar monarchy in now-independent Belgium, and the new regimes in the most industrialized cantons of Switzerland. ${ }^{9}$

In Britain, France, and Belgium prior to textile industrialization, the old absolutist monarchy had been displaced and the landed aristocracy had been diminished in power by revolutionary upheavals at one time or another. This meant that the textile industry could grow up in a relatively open political space, at least compared with the countries to the East and the South, and that it was easier for it to achieve its political aims.

In addition, the textile industries in the early industrializers were relatively competitive in the international market. This was most obviously true of Britain, "the workshop of the world," but even France, Belgium, and Switzerland were successful in selected international textile markets. This meant that for textile manufacturers in these countries, there was no conflict between the economic and the political parts of liberalism, between free trade and civil liberties. Again, this made it easier for the textile industry to develop a

\footnotetext{
'Quoted in Frederick B. Artz, op. cit., pp. 85-86.

' E. J. Hobsbawm, Industry and Empire: The Making of Modern Society, Vol. II, I759 to the Present Day (New York: Pantheon, 1968), chapters 3-4; William Langer, Political and Social Upheaval, 1832-1852 (New York: Harper and Row, 1969), chapters II-III.

'Langer, op. cit., chapters III-IV; Artz, op. cit., chapters VIII, IX; B. M. Biucchi, "The Industrial Revolution in Switzerland," in Cipolla, op. cit., pp. 627-652.
} 
coherent vision and then to develop, in Gramsci's sense, an ideological hegemony. The most dramatic example was the dominance of the doctrine of Manchester liberalism in Britain.

\section{The Prussian mutation}

The political impact of the textile industry was very different in the next or third wave of industrializers, Prussia and Austria, which experienced rapid growth in the industry only in the 1840s-1850s. Here, the Napoleonic Wars had displaced neither the old landed aristocracy nor its ally, the absolutist monarchy. Accordingly, the textile industry grew up in a relatively closed political space, cramped and contained by a well-entrenched agrarian upper class. ${ }^{10}$

One consequence was that textile industrialization in the East (1840s-1850s) was somewhat delayed from when it might have occurred and later than that in the West (1820s-1830s, even earlier in Britain). Yet, certain social groups in the East, in particular, students, professors, and lawyers, imported liberal ideas from the West during the Napoleonic Wars and the Restoration. The result was that a gap opened up between liberalism and industrialization. In the East in the 1810s-1830s, liberalism was a movement without much of a social base-what William Langer has called "the liberalism of the intellectuals" rather than the liberalism of the manufacturers. ${ }^{11}$ At this point liberalism outpaced industrialization.

A second, later consequence was that when textile industrialization did occur, the textile manufacturers would not be strong enough relative to the agrarian upper classes to impose their political vision on the rest of society. The new "infant industry" in the East was highly vulnerable in its domestic markets to competition from the older established textile manufacturers in the West, and accordingly the Eastern manufacturers were highly protectionist in regard to international trade policies. These features of the textile industry in the East diminished its liberal impulse and impact. The 1840 s to the 1860 s were the high point of liberal movements in the history of the Hohenzollern and Habsburg monarchies, yet liberal institutions never achieved the strength that they had in the West. At this point the gap between liberalism and industrialization continued but was reversed: industrialization outpaced liberalization.

Indeed, from the 1820 s to the 1860 s, the political economies of Britain and Prussia were almost mirror images. British textiles were competitive in the international market, while British grain was not. Conversely, Prussian grain was competitive in the international market, while Prussian textiles were not.

\footnotetext{
${ }^{10}$ On industrialization in Prussia and Austria, see Knut Borchandt, "The Industrial Revolution in Germany 1700-1914" and N. T. Gross, "The Industrial Revolution in the Habsburg Monarchy 1750-1914," in Cipolla, op. cit., pp. 76-156, 228-276.

${ }^{11}$ Langer, op. cit., chapter IV.
} 
Thus British textile manufacturers favored both free trade and liberal institutions, and British grain producers favored neither. Prussian textile manufacturers favored liberal institutions but not free trade, and Prussian grain producers favored free trade but not liberal institutions. The fact that British textile manufacturers could impose free trade upon British grain producers (the abolition of the Corn Laws in 1846) reinforced the social power of political liberals. Conversely, the fact that Junker grain exporters could impose free trade upon Prussian textile manufacturers (the low-tariff policy of the Zollverein) reinforced the social power of political conservatives. In Britain, economic liberalism worked to reinforce political liberalism; in Prussia, economic liberalism worked to undermine it. ${ }^{12}$

\section{The Latin pattern}

The political impact of the textile industry was very different again in the next or fourth wave of industrializers (Italy, Spain, and Portugal). Here, textile industrialization was delayed for a generation after that of Germany and Austria, two generations after that of France, Belgium, and Switzerland, and more than three generations after that of Britain. The countries of Latin Europe are thus the first severe case of "underdevelopment" or "dependent" industrialization. ${ }^{13}$

But like the East, the South also imported liberal ideas from the West during the Napoleonic Wars and the Restoration. Indeed, the first use of the term "Liberal" for a political group was in Spain in 1810, in the Constituent Cortes at Cadiz. Unlike the East, however, the social base of liberalism in the South also included military officers and bureaucratic officials, primarily because the old legitimate monarchies at the apex of the military and bureaucratic organizations had been displaced during the Napoleonic invasions. With such a social base, Southern liberalism was stronger than Eastern liberalism, whose social base was confined to intellectuals, but weaker than Western liberalism, whose social base included textile manufacturers. However, the absence of a new cohesive industrial class, the absence of the old cohesive agrarian class, and absence of the old legitimate monarchy combined to mean that for Latin Europe this was a period when no social group could exercise political authority, a period of military coups, popular revolts, and civil wars.

When textile industrialization did occur, the textile manufacturers could grow up in rough coequality with the agrarian upper classes. And this by the mid-1870s eventually issued in political stability and a special kind of liberal state, one based on a policy of tariff protection for both textiles and

\footnotetext{
${ }^{12}$ The economic basis of the contrast between Britain and Prussia is one theme discussed in Barrington Moore, Jr., Social Origins of Dictatorship and Democracy: Lord and Peasant in the Making of the Modern World (Boston: Beacon Press, 1966).

${ }^{13}$ On industrialization in Italy and Spain, see Luciano Cafagna, "The Industrial Revolution in Italy 1830-1914" and Jordi Nadal, "The Failure of the Industrial Revolution in Spain 1830-1914," in Cipolla, op. cit., pp. 279-325, 532-620.
} 
agriculture, a marriage of cloth and wheat comparable to the contemporary "marriage of iron and rye" in Bismarck's Germany. ${ }^{14}$

\section{The foreign export phase}

The British textile industry was the first to move into the second phase, the domestic stagnation phase, of the industrial life cycle. When the British textile industry reached the saturation point in its British markets and "the falling rate of profit," its natural, because minimal, response was to simply continue its old activity in a new place, i.e. it shifted from the selling of textiles in Britain to the selling of textiles in Europe. By the end of the Napoleonic Wars, 50-70 percent of British textile production each year was sold abroad. This was the motor behind the British foreign policy of free trade.

As the European market in turn became saturated, the textile industry shifted to the selling of textiles in Latin America. Here was the motor behind the British support of, and occasional intervention in, the Latin-American Wars of Independence. This combination of free trade and gunboat diplomacy would later be termed by John Gallagher and Ronald Robinson "the imperialism of free trade." 15 It probably reached its apogee in the Opium War of 1842 , near the end of the severe depression of $1837-1843 .{ }^{16}$ The transnational enterprise of this era of free trade was the trading company, the largest being the East India Company. The foreign policy of the British textile industry was summed up, again by Thomas Macaulay, in 1833:

It would be, on the most selfish view of the case, far better for us that the people of India were well-governed and independent of us, than ill-governed and subject to us; that they were ruled by their own kings, but wearing our broadcloth, and working with our cutlery, than that they were performing their salaams to English collectors and English magistrates, but were too ignorant to value, or too poor to buy, English manufactures. To trade with civilized men is infinitely more profitable than to govern savages. ${ }^{17}$

The success of British textiles in the international market led to the reinforcement of the British banking system of clearing houses, commercial

\footnotetext{
14 On Italian politics during the nineteenth century, see Arthur James Whyte, The Evolution of Modern Italy (New York: W. W. Norton, 1965); and Denis Mack Smith, Italy: A Modern History, revised edition (Ann Arbor: University of Michigan Press, 1969). On Spanish politics, see Gerald Brenan, The Spanish Labyrinth: An Account of the Social and Political Background of the Civil War (Cambridge: Cambridge University Press, 1950); and Joan Connolly Ullman, The Tragic Week: A Study of Anticlericalism in Spain, 1875-1912 (Cambridge, Massachusetts: Harvard University Press, 1968).

15 John Gallagher and Ronald Robinson, "The Imperialism of Free Trade," in George H. Nadel and Perry Curtis, editors, Imperialism and Colonialism (New York: Macmillan, 1964).

${ }^{16}$ E. J. Hobsbawm, Industry and Empire, chapter 7.

${ }^{17}$ Quoted in Michael Edwardes, The Last Years of British India (Cleveland: World Publishing, 1963), p. 234.
} 
banks, short-term credits, and now to insurance companies and to the expansion of its operations into the world arena. This kind of banking system, with its peculiar combination of short-term time horizons and worldwide space horizons, would have important implications for British domestic and foreign policies in later years.

There was another possible response to the saturation of domestic markets, however. That was to shift investment capital into a new industry, in this case the iron and steel industry and the railroads. This British investors did in the 1840s, and the result was the British boom of the 1850s. This choice between response one and response two, between foreign expansion and technological innovation, between producing an old commodity for a new country and producing a new commodity for the old country, was a crucial one. And the same crucial choice reappears as each new leading sector reaches its eventual and inevitable maturity and decline.

The textile industries of the other major European countries reached the saturation points of their own domestic markets at various times during the last three decades of the nineteenth century. The normal response of each country was to search for new markets in underdeveloped countries, particularly in a nation's colonial territories where the products of the national textile industry had a natural or even legal (e.g., tariffs) advantage over the products of foreign competitors. This drive for new colonial markets was one of the causes of "the new imperialism" of the late nineteenth century, including "the scramble for Africa" in the 1880s. But the textile industry by itself does not explain much about colonial policy. A more powerful engine propelling the new imperialism was the domestic stagnation phase of the steel industries of Europe.

\section{The political tendency of the steel industry}

\section{The domestic growth phase}

The second stage in the industrialization of a country normally has been the creation of a steel industry and the related creation of those industries which are the final consumers of steel-railroads, shipbuilding, and, in the twentieth century, automobiles.

The creation of a country's steel industry and its crucial consumer in the nineteenth century, the railroads, required the mobilization of far larger amounts of capital than that required in the creation of the textile industry. This distinction between the capital required for textile industrialization and that required for steel and railroad industrialization is one aspect of the distinction that Alexander Gerschenkron drew between early industrialization and late industrialization. ${ }^{18}$ Gerschenkron argued that in the late in-

\footnotetext{
18 Alexander Gerschenkron, Economic Backwardness in Historical Perspective (Cambridge, Massachusetts: Harvard University Press, 1962).
} 
dustrializers the need to mobilize large amounts of capital led to the need for financing by large investment banks or even by the state. This in turn led the investment banks to organize industrial cartels to prevent competition between the recipients of their investments. The complex of cartelized industry and industrial banks then was well-positioned to shape state policies. Or when the state itself undertook the financing of industrialization, it led to authoritarian measures. In Gerschenkron's view it was no accident that the late industrializers, in particular Germany, Austria-Hungary, Italy, and Russia were or eventually became authoritarian states. Guillermo O'Donnell has reached similar conclusions in analyzing Latin-American countries. O'Donnell argued that in these still later industrializers the move from the consumer-goods stage of industrialization into the capital-goods stage of industrialization generates severe balance of payments problems, the need to mobilize large amounts of capital, and again the turning of economic and technocratic elites to the solution of the "bureaucratic-authoritarian" regime, as in Brazil in 1964 and in Argentina in 1966. ${ }^{19}$

The actual evidence for the causal connection between the steel industry and authoritarian politics is rather mixed. In the first industrializer, Britain, the mobilization of capital for the second stage of industrialization occurred without any dramatic change in financial institutions or in state intervention. Indeed, the mobilization of capital for the British iron and steel industry and for the British railroads was achieved about as easily and as incrementally as the mobilization of capital for the British textile industry. But in Britain the ease of capital mobilization for iron, steel, and railroads was itself a consequence of the prior overwhelming success of British textiles in foreign markets, which generated large profits and large amounts of capital for investment in new enterprises. From the 1820 s to the 1850 s, textile exports normally formed 40-60 percent of Britain's exports each year. ${ }^{20}$

In France, the pattern was somewhat different. After a slow growth of the iron industry and of railroads before 1848, France experienced rapid growth in these sectors in the 1850s and 1860s. It is an oft-told tale that this rapid growth required new financial institutions, such as investment banks (e.g., the Crédit Mobilier of the Pereire brothers); in turn, these new investment banks, it is said, needed the support of a strong state (i.e., the Second Empire of Napoleon III, 1852-1870) to break the power of the traditional banks. ${ }^{21}$ Indeed, a

\footnotetext{
${ }^{19}$ Guillermo A. O'Donnell, Modernization and Bureaucratic-Authoritarianism: Studies in South American Politics (Berkeley: International Studies, University of California, Berkeley, Politics of Modernization Series No. 9, 1973).

${ }^{20}$ Hobsbawm, Industry and Empire, chapters 6 and 7. A useful overall account of the growth and impact of the European iron and steel industries and railroads is Hobsbawm's The Age of Capital, 1848-1875 (New York: Charles Scribner's Sons, 1975).

${ }^{21}$ See, for example, Gerschenkron, op. cit., and Rondo E. Cameron, France and the Economic Development of Europe, 1800-1914, Conquests of Peace and Seeds of War (Princeton: Princeton University Press, 1961), chapter IV.
} 
good case can be made that the first in the endless parade of modern bureaucratic-authoritarian regimes was the French Second Empire.

The Third Republic, which replaced the Second Empire after its defeat in the Franco-Prussian War in 1870, was not an authoritarian regime. Yet in the 1880s it organized and supported, through the Freycinet Plan, another major expansion of the French steel industry and the French railroads. ${ }^{22}$ This casts doubt on the argument that steel and railroad industrialization in France required an authoritarian regime. On the other hand, just as in Britain in the first half of the nineteenth century, so too in France in the 1880s, the export of textiles provided the capital to finance the expansion in iron, steel, and railroads. During this period, textile exports normally formed 30-50 percent of France's exports each year. In Britain, the expansion was financed by British domination of the international markets for low-price cotton goods; in France, the expansion was financed by French domination of the international market for high-quality goods, especially woolen ones. It was France's special vocation in the quality products of the last stage of the pre-industrial era which eased its transition through the second stage of the industrial revolution-and made it easier to do without the discipline of another authoritarian regime. ${ }^{23}$

In Germany, the path to steel and railroad industrialization was very different from that in either Britain or France. At the time Prussia and then Germany undertook this second stage of industrialization, it had achieved no dominance of the world market for any product of the first stage, that of textiles. Accordingly, there was an absence of large profits from foreign trade and thus of large amounts of capital to be invested in steel and railroads. There was therefore a need for new kinds of financial institutions, specifically industrial investment banks or state enterprises. ${ }^{24}$ And there was also a relatively open space in the German financial system within which these new institutions grew and indeed reached a dominant position. As in Britain where the weakness of the agrarian elites had permitted the textile industry and commercial banking to grow up unconfined and to eventually dominate the political system, so too in Germany the weakness of the textile industry and commercial banking (itself due to the strength of the agrarian elites, the Junkers) permitted the steel industry and industrial banking to grow up unconfined and eventually to dominate.

By the end of the long prosperity of 1850-1873, sometimes known as the

${ }^{22}$ Sanford Elwitt, The Making of the Third Republic: Class and Politics in France, 1868-1884 (Baton Rouge: Louisiana State University Press, 1975), introduction and chapter I.

${ }^{23}$ William Woodruff, "The Emergence of an International Economy, 1700-1914," in Cipolla, op. cit., pp. 673-674.

${ }^{24}$ See, for example, Gerschenkron, op. cit., and Cameron, op. cit., chapter IV. A useful and detailed discussion of the relationships between economics and politics in Germany under Bismarck is presented by Fritz Stern, Gold and Iron: Bismarck, Bleichroder, and the Building of the German Empire (New York: Alfred A. Knopf, 1977). 
great railroad boom, Britain and Germany had each institutionalized the respective methods by which they had passed through the first and second stages of industrialization. Britain represented the overdevelopment of the first stage of the industrial revolution, composed of the textile industry and commercial banking. Germany represented the overdevelopment of the second stage of the industrial revolution, composed of the steel industry and industrial banking. Even more, however, Germany represented the overdevelopment of the coalition between the last stage of the pre-industrial era, that of commercialized agriculture, and the second stage of the industrial one-what was to become in 1879 the famous "marriage of iron and rye." France took a middle position between the two, having a political economy more balanced between the agricultural, the textile, and steel sectors, between domestic and foreign markets, and between commercial and investment banking.

In Britain, France, and Germany, the iron and steel industry and the railroads developed together, as a sort of "steel-rail complex." In Italy and Spain, however, this nexus was severed. The major railroads of Latin Europe were built with rails and rolling stock imported from Britain and France and were financed with capital loaned by British and French investment banks. ${ }^{25}$ The result was railroadization without steel industrialization. Since the capital mobilization for the railroads of Latin Europe came from foreign investors rather than from the national government, from abroad rather than from above, no dramatic reorganization of the state was necessary. It is not surprising, therefore, that the construction of the railroads of Italy and Spain in the mid- and late-nineteenth century could coexist with the conservation of their liberal institutions and parliamentary systems.

Italy did construct a substantial steel industry in the $1900 \mathrm{~s}$, however. (Spain would not do so until after World War II.) But, as in Britain and in France in earlier times, the necessary capital mobilization in Italy was made possible by the export of textiles. In Italy's case, it was Italian domination of the international market for high-quality silk products. It was also another case where the second stage of the industrial revolution was financed by the achievements of the last stage of the pre-industrial era. ${ }^{26}$

Most later steel industrializers, such as Spain, Brazil, and Argentina, lacked the capability to dominate the international market for a particular industrial product. This led them into severe balance of payments difficulties (even though they were exporters of agricultural products), once they tried to move from the stage of textile or "import-substitution" industrialization to the stage of steel or capital-goods industrialization. The conjunction of the need to mobilize large amounts of capital and severe balance of payments deficits leading to devaluations and severe inflation created an influential constituency among economic, bureaucratic, and technocratic elites in support of

\footnotetext{
${ }^{25}$ Cameron, op. cit., W. O. Henderson, Britain and Industrial Europe: 1750-1870: Studies in British Influence on the Industrial Revolution in Western Europe, third edition (London: Leicester University Press, 1972).

${ }^{26}$ Cafagna, op. cit., pp. 289-290, 302-325.
} 
an authoritarian regime. In contrast with a liberal, parliamentary system, an authoritarian regime was better able to destroy labor unions, repress wages and consumer demand, and thus squeeze capital out of the working class in order to finance the new capital-goods sector.

\section{The foreign export phase and the naval procurement phase: from the Great Depression of 1873-1896 to World War I}

The most pronounced impact of the steel industry upon political outcomes came, not in its phase of domestic growth, but in its phase of domestic stagnation, that is, after steel production reached saturation in its home markets, and the industry turned to foreign ones. And because the responses of Britain to this phase in the nineteenth century can be seen as prototypes of many American industrial policies in the mid-twentieth century, we shall discuss the British experience at some length. ${ }^{27}$

\section{Britain}

The British iron industry (it would not become a steel industry proper until the adoption of the Bessemer process in the 1860s) and the associated railroads fueled the British boom of 1851 to 1857. A brief depression from 1857 to 1859 led the British to push for a series of international treaties to promote free trade, such as the Cobden-Chevalier treaty of 1860 between Britain and France. The 1860 s were relatively prosperous. During this period some banks of the City of London began the large-scale financing through bonds of railroads on the Continent, many of them built with British rails and British equipment. ${ }^{28}$

By the beginning of the 1870 s, however, railroad-building in Britain had reached the saturation point, and to a lesser degree the same was true of Britain's railroad-building on the Continent. An economic historian (who later went on to other things) once asked "What happened when the railroads were built?" 29 His answer was "the Great Depression of 1873-1896." Although other factors also contributed to the long economic depression after 1873, such as the entry into the world markets of massive amounts of cheap grain from the American midwest, which sharply drove down European grain prices, the peaking of railroad-building in Europe was certainly a central factor. ${ }^{30}$

\footnotetext{
${ }^{27}$ See the comparison between Britain and America drawn by Robert Gilpin, op. cit.

${ }^{28} \mathrm{~W}$. O. Henderson, op. cit.

${ }^{29} \mathrm{~W}$. W. Rostow, British Economy in the 19th Century (Cambridge: Cambridge University Press, 1948), p. 88. (Rostow originally developed his argument in 1938.)

${ }^{30}$ The connections between the end of railroad expansion and the beginning of the Great Depression are also discussed in Hobsbawm, Industry and Empire. An excellent comparative analysis of the politics of the Great Depression is Peter Alexis Gourevitch, "International Trade, Domestic Coalitions, and Liberty: Comparative Responses to the Crisis of 1873-1896," The Journal of Inter-Disciplinary History, VIII (Autumn, 1977): 281-313. An earlier classic account is Hans Rosenberg, "Political and Social Consequences of the Great Depression of 1873-1896 in Central Europe," Economic History Review, XIII (1943): 58-73.
} 
What was the response of the British steel industry and of the bond-dealing banks of the City of London to the saturation of their former markets and more generally to the Great Depression? Again, the first response was simply to continue their old activity in a new place, i.e., they shifted the building and financing of railroads from Britain and the Continent to the "regions of recent settlement"' (i.e., the United States, Canada, Australia, and Argentina) and to the regions on the borders of Europe (e.g., Turkey and Egypt). In some of the latter regions, however, the inability of weak and corrupt governments to meet their bond payments led Britain in the 1870s and 1880s into interventions and even annexations. Thus began the first steps toward "the new imperialism." Of course, the factors making for "the new imperialism" were many, and historians have developed a variety of explanations, such as strategic calculation, bureaucratic activities, and popular moods. The industrial and financial factor, however, seems to have been an especially consistent and common one. ${ }^{31}$

The change that took place in the minds of some industrialists, after the beginning of the depression in 1873, was registered by William Menelaus, a leading steel manufacturer, in his presidential address to the British Iron and Steel Institute in 1875:

We have but little demand from Europe, and we seem to have lost our American market entirely. . . . We must, I think, frankly accept the position in which we are placed, and prepare to seek new markets for our produce in countries which, even if they have the will, have not yet the power to impose restrictions on our trade. ${ }^{32}$

In their new foreign policy, the steel industry had allies, of course, in the textile industry, who were also suffering from the depression and who were already familiar with the advantages of "the imperialism of free trade."

However, even the new overseas receptacles of British textiles and steel soon reached the saturation point or at least the law of diminishing returns. The result was a new, sharp business downturn, the depression of 1883, within the overall Great Depression of 1873-1896. Again, the minimal response was to expand the old activities into new countries, reinforcing "the new imperialism" and "the scramble for Africa" of the 1880s.

E. J. Hobsbawm summarizes this crucial choice of Britain in response to the Great Depression:

She was too deeply committed to the technology and business organization of the first phase of industrialization, which had served her so well, to advance enthusiastically into the new and revolutionary technology and

${ }^{31}$ Various aspects of imperialism are analyzed in Roger Owen and Bob Sutcliffe, editors, Studies in the Theory of Imperialism (London: Longman, 1972).

${ }^{32}$ Quoted in J. C. Carr and W. Taplin, History of the British Steel Industry (Cambridge, Massachusetts: Harvard University Press, 1962), p. 39. 
industrial management. . . . This left her with only one major way outa traditional one for Britain, though one also now adopted by competing powers - the economic (and increasingly the political) conquest of hitherto unexploited areas of the world. In other words, imperialism. ${ }^{33}$

The choice was in part the result of the British banking system. The absence of strong investment and industrial banks meant that it was especially difficult for Britain to mobilize capital for long-term equity investment in new technologies and industries.

The second response of the British steel industry to the Great Depression and in particular to the depression of 1883 was the building of steamships. ${ }^{34}$ Just as the railroads brought cheap grain and meat from the hinterlands to the ports of the regions of recent settlement, so the steamships brought them from these ports to Britain. But these receptacles, or rather vessels, of British steel, also soon reached the saturation point. The result was another sharp business downturn, the depression of 1893, within the overall Great Depression.

The third response of the British steel industry to the Great Depression, in particular to the depressions of 1883 and 1893, was again a minimal move. Having built commercial ships, it was natural enough that the next step was to build naval ships. The beginning of the depression of 1883 was followed by the "navy scare" of 1884 and by a 20 percent increase in the British naval budget in 1885, the largest increase since the Crimean War. The beginning of the depression of 1893 was followed by another navy scare of 1893-1894 and by another 20 percent increase in the British naval budget in 1894, regularized in the Spencer naval program of 1894 which laid plans for further increases in the next few years. ${ }^{35}$ The industry journal, Iron and Coal Trades Review, observed in March 1895 that the effect of the Admiralty program

has been to enable private firms to tide over without disaster periods of depression that would otherwise have been extremely trying; and, naturally, we have seen that the same policy has stimulated local and provincial interest in naval affairs to a much greater extent than was formerly the case. ${ }^{36}$

The use of naval procurement as countercyclical policy seems to have continued even after the end of the Great Depression in 1896. The beginning of the less severe depression of 1900-1904 was followed by another sharp increase in the naval budget in 1901, and even the decision in 1904 to build the Dreadnought can be interpreted as another example of Keynesianism before Keynes.

${ }^{33}$ Hobsbawm, Industry and Empire, p. 107.

${ }^{34}$ Rostow, The World Economy, p. 381.

${ }^{35}$ Data on the naval budgets of Britain and other European powers are given in Kendall D. Moll, The Influence of History Upon Seapower, 1865-1914 (Menlo Park, California: Stanford Research Institute, 1969).

${ }^{36}$ Quoted in Arthur J. Marder, The Anatomy of British Sea Power: A History of British Naval Policy in the Pre-Dreadnought Era, 1880-1905 (New York: Alfred A. Knopf, 1940), p. 36. 
Thus it was that by the beginning of the twentieth century, Britain had abandoned its industrial vocation for an imperial one. In 1851, "the workshop of the world" had dazzled Europe with the first industrial world's fair, The Great Exhibition at the Crystal Palace. Fifty years later, the scene was just as splendid but rather different:

Never were instruments of war so gleaming with brass, so brilliant of paintwork, so stately with ensigns and bugle-calls and white canvas. The fleet which, in 1901, King Edward VII reviewed at Spithead at the close of the Victorian era offered perhaps the most gorgeous spectacle of power Europe has ever seen: the ships were painted in black, white and yellow, and fluttered all over with signal flags and pennants, and from their topmasts flew gigantic White Ensigns and crosses of St. George, and their crews jauntily linked the decks, and their officers majestically saluted from their high bridges, and through the line of warships came the King of England in his royal yacht, the largest steam yacht in the worldstandard at the mainmast, duty officers at attention on the foredeck, a wispy stream of smoke from two bright yellow funnels, and beneath the cheers of the assembled crews and the successive melodies of the battleship bands, the soft greased thump of reciprocating engines from impeccable engine-rooms below. ${ }^{37}$

The British steel industry now faced vigorous competition in its colonial and even home markets from the more efficient German and American steel industries. The emerging British electrical and chemical industries, underdeveloped because of the foreign orientation of the British financial system, also faced vigorous competition from their more efficient German and American counterparts, nourished and guided by investment and industrial banks. More broadly, the small island-state serving as the head of a far-flung, loosely-knit, sea-borne empire faced vigorous strategic competition from Germany and America as two great continential powers. The liberal vision of free trade and free capital movements in a world arena was nearing exhaustion, or at least bringing about the industrial and strategic exhaustion of Britain while preserving the prosperity of the City of London.

For a brief moment, British heavy industry put forward an alternative vision of the British future. It did so under the leadership of Joseph Chamberlain, a leader of the Conservative Party and a former mayor of Birmingham, the center of the British steel industry ${ }^{38}$ Chamberlain and his supporters proposed that Britain erect tariff walls around much of its empire and that the dominions be compensated with greater participation in political decision making in London-imperial preference and imperial federation. The result

\footnotetext{
37 James Morris, “A View of the Royal Navy," Encounter XL (March 1973): 20.

38 Bernard Semmel, Imperialism and Social Reform: English Social-Imperial Thought 1895-1914 (Cambridge, Massachusetts: Harvard University Press, 1960).
} 
would be a British world power with industrial and strategic strength equal to or greater than that of Germany and America. And together these three great "Saxon" powers would essentially divide much of the world into three spheres of influence and would no longer pursue conflicts of interest between themselves.

The defeat of British heavy industry and of Chamberlain's vision, finalized in the Liberal electoral victory of 1906, was probably over-determined. A key role in the new imperial order would have been played by Canada. But many Canadian economic interests wanted access to cheap American capital-goods, and by this time there were some Canadian industrialists who wanted their own tariff walls against all foreign goods, including British ones. But the decisive attack on the industrial and imperial vision came from within Britain itself and was organized by the banks of the City of London which wanted to maintain the benefits from being the center of a system of free movement of goods and capital with the world as its arena. The banks were supported by many within its old ally, the textile industry, who still believed they could compete in cotton textiles. The long hegemony of the banking system in British politics meant that this particular tale of two cities, of London and Birmingham, would not have a surprise ending.

The British steel industry was not strong enough, then, to displace the liberal vision and to impose its own. It was strong enough, however, to exact compensation in the form of renewed naval procurement and to justify the grand new battleships by pointing to the German menace in the years down to 1914.

Other nations also turned to vigorous state action during the Great Depression of 1873-1896 and later, in order to maintain their steel industries and the returns to capital in them.

\section{France}

Like its British counterpart, the French steel industry also was afflicted by the Great Depression of 1873-1876. The first response was, as we have already suggested, the state-supported expansion of the French railroad network under the Freycinet Plan of 1878. A second response was similar to that of Britain, a search for overseas markets. Jules Ferry, who had long represented the iron and steel industry of Eastern France, initiated an annexationist colonial policy when he was Premier in 1881. But this colonial policy was somewhat premature and was only fitfully pursued in the 1880 s, when the major thrust of state policy was the completion of the railroad network.

What happened after the French railroads were built? The depression of 1892. One response to this new downturn was the famous Méline Tariff of that year, the first high French customs barrier since before 1860. Another response was a reinvigorated colonial policy which lasted until the eve of 
World War I. But the most substantial response was to build and finance railroads in Russia with French equipment and capital and to buttress this grand railroad undertaking with the Franco-Russian Alliance of 1894. ${ }^{39}$

\section{Germany}

The German steel industry and its associated industrial banks also were afflicted by the Great Depression. But the actions of the German state not only combined the various measures of the British and the French but included some innovative measures of its own.

The first response was a minimal move, the tariff of 1879 . This tariff was a central component of the coalition between German industrialists and Junker agrarians, "the marriage between iron and rye," and 1879 has been called the Second Founding of the Second Empire. In the same year, the Anti-Socialist Law was enacted. And at about the same time, the state undertook the legal enforcement of cartel agreements to limit production and maintain prices. ${ }^{40}$

Yet tariff and cartel protection alone could not prevent the saturation of the steel industry's German markets, and Germany also experienced the depression of 1883 . Germany then turned rather tentatively to what had been the first response of Britain, a search for overseas markets. Bismarck initiated a colonial policy in 1884 , one which was not vigorously sustained. Bismarck also initiated a 20 percent increase in the German naval budget in the same year. The return of depression in 1890 was followed by a 60 percent increase in the German naval budget of 1891. The Germans, like the British before them, anticipated Keynes. The depressions of 1901 and 1908 were also followed quickly by unusual increases in the German naval budget. ${ }^{41}$ At the same time, diplomatic efforts promoted foreign railroads, especially the Baghdad Railway, which were built with German steel and capital but which posed a threat to British economic and strategic interests.

Thus, by the beginning of the twentieth century, the steel industries of both Britain and Germany were focused on the building of warships, and the Anglo-German naval race was on. As the years went on, the naval race took on a reciprocal dynamic of its own. But it is interesting to note that most major jumps in the British and the German naval budgets occurred in a year or two after a downturn in the business cycle.

\footnotetext{
${ }^{39}$ Cameron, op. cit., and François Caron, "French Railroad Investment, 1850-1914," in Essays in French Economic History, Rondo Cameron, editor (Homewood, Illinois: Richard D. Irwin, 1970), pp. 315-340.

${ }^{4}$ On this coalition between industrialists and Junkers, see Alexander Gerschenkron, Bread and Democracy in Germany (Berkeley: University of California Press, 1943); also V. R. Berghahn, Germany and the Approach of War in 1914 (New York: St. Martin's Press, 1973).

${ }^{41}$ Moll, op. cit., The classic analysis of the political economy of German naval procurement is Eckart Kehr, Battleship Building and Party Politics in Germany 1894-1901 (Chicago: University of Chicago Press, 1975). (Kehr's book was originally published in Germany in 1930.) Also see Berghahn, op. cit.
} 
The Anglo-German naval race did not in itself lead to World War I. It did, however, place a barrier to any enduring Anglo-German détente, and it did lead to the Anglo-French naval entente of 1904. All of this, in turn, loaded the dice toward the particular form the alliance system took by 1914 .

One other German response to saturation in old industries was more innovative, however, and that was the creation of two new capital-goods industries, electricity and chemicals. The German industrial banks facilitated such industrial innovation. State measures also provided important support, especially the funding of technical and science education, the reform of municipal government to provide financial security for urban electric railroads and electric power systems, and, of course, military and naval procurement of explosives manufactured by the chemical industry. ${ }^{42}$

\section{Italy}

The Italian steel industry was largely constructed in the 1900s. Even more than the preceding steel industries it was dependent upon state contracts and guarantees. Almost immediately, it became a major force for a vigorous foreign policy to achieve railroad concessions in the Balkans (especially, and rather pathetically, in Montenegro and Albania) and in the Ottoman Empire, and a force for a major buildup of the Italian navy. ${ }^{43}$ Indeed, in the last years before World War I, there was something of a railroad war between Italy and Austria-Hungary in the Balkans. It was this rivalry which gradually separated Italy from its cooperation with Germany and Austria-Hungary in the Triple Alliance, and it was this search for new colonial territories to the East which drove Italy into the War on the side of the Triple Entente of Britain, France, and Russia in 1915.

The foreign export and military procurement phases recycled: from World War I to the Great Depression of 1929

On the morrow of World War I, the steel industries of Europe and also of America, were again faced with the old problem: how to keep themselves in business, after the period of postwar reconstruction came to its inevitable end. There was a choice of several paths.

\section{Britain}

The British, in keeping with their practice of the minimal move, of muddling through, for the most part chose simply to do more of the same. They retained their overseas empire after the war, and thus they could con-

\footnotetext{
${ }^{42}$ W. O. Henderson, The Rise of German Industrial Power, 1834-1914 (Berkeley: University of California Press, 1975).

${ }^{43}$ R. A. Webster, Industrial Imperialism in Italy, 1908-1915 (Berkeley: University of California Press, 1975).
} 
tinue to build railroads to span their colonies, steamships to service them, and warships to defend them, i.e., they could continue in each of their three responses to the Great Depression of 1873-1896. In addition, however, they at last began the transition to a new leading sector. Having based much of their earlier industrialization on textiles and having had high earnings from foreign trade and investment, the British had, more than other European countries, a consumer-oriented economy and high per capita income. Accordingly, they possessed in 1920 the second largest (after the Americans) automobile industry in the world, and this experienced a slow but steady growth during the 1920 s.

\section{France}

The French recapitulated the British pattern, but in a reduced form. Before the war, their empire, their earnings from textile (especially woolen) exports, and their earnings from foreign investment had each been second only to Britain's. After the war, they too poured the output of their steel industry into more colonial railroads, steamships, and warships and also into a small automobile industry, which nevertheless was the third largest automobile industry in the world.

\section{Germany}

The Germans, having lost the war and having remained a country without a strong consumer goods sector, had in 1920 neither an overseas empire nor an automobile industry. For the German steel industry, consequently, there seemed to be only two feasible paths, and these were mutually reinforcing. One was renewed armaments production. The other was exports of steel products to markets in Eastern Europe and, relatedly, gaining control over the growing and competing steel industries of Austria, Czechoslovakia, and Poland. Throughout the 1920 s, the steel industry supported those political parties which in turn supported rearmament, revision of the Treaty of Versailles, tariff barriers against Western Europe, and German domination of Eastern Europe. Its favorite political vehicle was the National People's Party, led by Alfred Hugenberg. ${ }^{44}$ The steel industry was joined in its support by the Junker agrarians, making the National People's Party a renewal of the old marriage of iron and rye. The Junkers, imbued with military traditions and threatened by cheap grain imports from Poland, had their own reasons for rearmament, revision of Versailles, and domination of Eastern Europe.

\footnotetext{
44 The politics of the German steel industry during the 1920s are discussed in Gerald D. Feldman, Iron and Steel in the German Inflation, 1916-1923 (Princeton: Princeton University Press, 1977); Charles S. Maier, Recasting Bourgeois Europe: Stabilization in France, Germany, and Italy in the Decade After World War I (Princeton: Princeton University Press, 1975); and David Abraham, Inter-Class Conflict and the Formation of Ruling Class Consensus in Late Weimar Germany (Doctoral dissertation submitted to the Department of History, University of Chicago, December 1977).
} 
By the 1920s, however, the German economic scene included two other leading sectors, the chemical industry and the electrical industry, and these had a very different political tendency. The German chemical industry was the second largest and the most advanced chemical industry in the world. (Its leading enterprise, I. G. Farben, was the world's largest chemical corporation and the largest corporation of any in Europe. $)^{45}$ This meant that the chemical industry had a strong interest in free trade or at least in conditions which encouraged exports. The same was true of the German electrical industry which was the largest and the most advanced electrical industry in Europe. And since the largest and best markets for chemical and electrical products were other advanced industrial economies, these two industries were vitally interested in good relations with Western Europe. This led them to support those political parties which in turn supported "fulfillment" of the Versailles Treaty and the concluding of the Locarno Treaty of 1925 between Germany and its Western neighbors. Conversely, they were basically indifferent to Eastern Europe in the 1920s (and there was never an "Eastern Locarno"). The favorite political vehicle of the chemical and industrial industries was the German People's Party, led by Gustav Stresemann. ${ }^{46}$

In addition to their interest in free trade, the chemical and electrical industries also had an interest in promoting mass consumption and therefore in supporting social welfare and democratic politics. I. G. Farben, encouraged by the widespread consensus among experts in the 1920s that world petroleum supplies would soon be exhausted, diverted most of its new capital investments into building enormous plants to produce gasoline from coal by a process known as hydrogenation. ${ }^{47}$ It thus acquired a strong interest in the development of a large German automobile industry. Similarly, the German electrical industry, a producer of consumer durables and municipal electrical equipment, also had a strong interest in social welfare and municipal services. These features led the industries into supporting parliamentary coalitions which included the Social Democratic Party. In brief, then, the Weimar Republic, with its foreign policy of "fulfillment" and its domestic policy of social welfare, was in many ways based upon a coalition of chemistry, electricity, and labor in opposition to the coalition of iron and rye. ${ }^{48}$

The Weimar system was in an unstable equilibrium, however. Its major leader, Stresemann, died in October 1929. At the same time, the New York stock market crash marked the beginning of a new Great Depression. The American responses to the economic crisis had momentous consequences for

${ }^{45}$ On 1. G. Farben, see Frank A. Howard, Buna Rubber: The Birth of an Industry (New York: D. Van Nostrand, 1947); and Joseph Borkin, The Crime and Punishment of I. G. Farben (New York: The Free Press, 1978), an informative and perceptive industrial history, which goes beyond the connotations of its title.

46 The politics of the German chemical and electrical industries during the 1920 s are discussed by Maier, op. cit., and Abraham, op. cit.

${ }^{47}$ Howard, op. cit.; Borkin, op. cit., chapter 2.

Abraham, op. cit., presents a thorough and sophisticated demonstration of this argument. 
Germany. The Smoot-Hawley Tariff of 1930 led to the raising of tariff barriers in other countries, dealing a serious blow to the free trade policies of the German chemical and electrical industries. In addition, the drying up of American loans to Germany broke a crucial link in the international economic chain which had lifted up German prosperity in the 1920s (American loans to Germany - German reparations to Britain and France - British and French imports from Germany). These two developments meant that the free trade option, the Westpolitik, of the chemical and electrical industries suddenly became far less viable. And they meant in turn that the coercive trade option, the Ostpolitik, of the steel industry suddenly became most attractive. Finally, the depression-induced sharp drop in world oil prices in 1930-1931 and the opening up of the vast East Texas oil field in 1931 meant that I. G. Farben, with its enormous investments in hydrogenation plants, was suddenly threatened by massive imports of cheap American oil, much as the Junker agrarians had suddenly been threatened by massive imports of cheap American grain sixty years before. For I. G. Farben, the only solution to the Texan problem was a German government which would be strong enough and willing enough to guarantee a market for its coal-based gasoline, by erecting tariff barriers, by granting subsidies, by buying the gasoline itself, and by legitimating the vast expenditures entailed with an ideology of economic autarky and military preparedness-i.e., the same ideology promoted by the steel industry and the grain producers. ${ }^{49}$

Together, these new developments in the world market propelled the chemical and electrical industries during 1932 from political opposition into political cooperation with the steel industry and the grain producers. And as the National People's Party under Hugenberg proved insufficiently popular to win the several elections of 1932, first the steel industry and then the chemical and electrical industries shifted their financial support to the National Socialist Party under Hitler. ${ }^{50}$ With the coming to power of the Nazis in 1933, the foreign policy of the steel industry-rearmament, revision of Versailles, high tariffs, and domination of Eastern Europe-became the foreign policy of the new Germany.

\section{Italy}

The German experience had had an earlier and a simpler trial run in Italy. Of all the European steel industries before World War I, the Italian had been the most dependent upon armaments contracts. It was, therefore, unusually vulnerable to a period of peace, especially one in which the peace treaties, like

\footnotetext{
${ }^{49}$ Borkin, op. cit., chapter 3.

${ }^{\text {so }}$ Abraham, op. cit.; Borkin, op. cit., chapter 3. On the industrial role in the 1932 elections, also see Alan Bullock, Hitler: A Study in Tyranny, revised edition (New York: Harper and Row, 1964). An earlier, classic account of the relations between industry and the Nazis is Franz Neumann, Behemoth: The Structure and Process of National Socialism (New York: Oxford University Press, 1942).
} 
Versailles, gave Italy no substantial territories on which new railroads could be laid. The inevitable postwar economic depression hit Italy in 1921 especially hard. Accordingly, the steel industrialists supported popular movements demanding revision of "the mutilated peace" and the annexation of new territories. The major such movement, the Fascists, achieved power in 1922..$^{\text {s1 }}$ But Italy's efforts at territorial expansion would have to wait for more than a decade until the new Great Depression produced a diplomatic constellation of the greater powers which was more favorable to Italian aims.

We have seen the range of the different countries' responses. Given the historical British response to the combination of the Great Depression of 1873-1896 and the German naval buildup of the 1890s, one might have thought that the British response to the new Great Depression and the German rearmament of the 1930s would have been similar, i.e., British rearmament. But, of course, this was not the case. Instead, the actual British response was rather like Joseph Chamberlain's program of the early 1900s, i.e., imperial preference and appeasement of the Germans.

Part of the explanation lies ironically in the continuing hegemony of the British system of commercial banks operating in a world arena, of the same City of London that had defeated the Chamberlain program thirty years before. In "the terrible year" of 1931, there were massive runs on the pound and on the British commercial banks, and the government installed emergency capital controls. But the City of London needed to return as soon as possible to free movements of capital. The lesson that had been learned in 1931 was that the pound was now vulnerable in the face of even slight economic and political disturbances. A small sign of inflation or a small decline in the balance of trade could lead to a new run on the pound and a new financial collapse.

In domestic affairs, this meant that Britain could not increase consumer-demand to the point that the wages of skilled labor were bid up, resulting in inflation, or that more raw materials were imported, resulting in a decline in the balance of trade. Thus Britain went through the 1930s with the government making no serious efforts at eliminating unemployment through Keynesian measures promoting mass consumption. ${ }^{52}$ In colonial affairs, the extreme sensitivity toward the balance of trade meant that orderly, predictable markets for British exports were now highly valued. Thus, the City of London was now willing to accept imperial preference, formalized in the Ottawa Agreements of 1932.

In foreign affairs, the consequences were even more momentous. Just as the wage or raw-material dynamic could be detonated by government-induced consumer spending, so could it be detonated by government-ordered defense spending, i.e., rearmament. The City of London, haunted by the ghost of

\footnotetext{
${ }^{51}$ Roland Sarti, Fascism and the Industrial Leadership in Italy, 1919-1940 (Berkeley: University of California Press, 1971).

${ }^{32}$ Donald Winch, Economics and Politics: $A$ Historical Study (London: Hodder and Stoughton, 1969).
} 
1931, imposed a low ceiling upon rearmament efforts and thus a narrow scope upon British foreign policy. In every diplomatic confrontation with Nazi Germany and Fascist Italy in the 1930s, British foreign policy was severely constrained by the immediate need to prevent a foreign exchange crisis and by the military weakness resulting from minimal rearmament efforts. When Neville Chamberlain, the son of Joseph Chamberlain, moved from being Chancellor of the Exchequer to being Prime Minister in 1937, he was determined to accept these financial realities and to act accordingly in a coherent and systematic way. The result was his foreign policy of Appeasement. ${ }^{53}$

These, then, were the various responses of the different European nations to the continuing problems of saturation in their steel industries in the years following World War I. There was, however, yet another possible response, and that was to develop fully a massive new leading sector, in particular the automobile industry, and to pour steel into it. And this was the path taken by the United States.

\section{The political tendency of the automobile industry}

\section{The domestic growth phase}

The impact of an automobile industry upon an economy is so great that it is justifiable to see the creation of that industry as a new stage in the industrialization of a country.

It was the Americans, who with an almost single-minded intensity, first took this path. On the eve of the innovation of the automobile, the United States already had developed the most consumer-oriented economy and the highest per capita income in the world. It also included a large class of prosperous, independent farmers, many exporting to European markets, who were separated by long distances from their market towns and from each other and who provided a perfect market for the automobile. It is not surprising, therefore, that even before World War I, the United States possessed the largest automobile industry in the world, both in terms of absolute numbers of cars produced and in terms of cars per capita (about one car per thirty-five persons in 1914). ${ }^{54}$

The "start-up costs" for automobile production were actually rather low, as long as a manufacturer was interested in producing only a few cars. Thus, manufacturers of bicycles and buggies could rather easily convert to automobiles. However, the advent of mass-production and assembly-line techniques meant that success would go to companies that could raise enormous amounts of capital, either through their profits (Ford) or through out-

\footnotetext{
${ }^{53}$ Robert Paul Shay, Jr., British Rearmament in the Thirties: Politics and Profits (Princeton: Princeton University Press, 1977).

${ }^{34}$ On the early developments of the automobile industry in the United States, see James J. Flink, The Car Culture (Cambridge, Massachusetts: The M.I.T. Press, 1975).
} 
side financing. One of the heroic moments of American capitalism was the decision by the Du Ponts, who had accumulated massive profits producing munitions for World War I (and who were confronted with a massive collapse of their markets with the advent of peace), to finance a struggling automobile company, which in 1919 had little grand about it except its name-General Motors. By 1926, General Motors was the world's largest automobile company.

The boom in the American automobile industry in the 1920s fueled the more general boom in the American economy, "the New Era." As steel poured into automobiles ( 30 percent of American steel production went into automobiles by the mid-1920s), the steel industry was released from the need for armaments contracts. There was therefore no leading American industry with an interest in "foreign entanglements" or a "military-industrial complex." The Washington Naval Conference of 1922, with its limitation on capital ships, registered this American shift from ships to cars, from the Great White Fleet to the black Model T, from manifest destiny to consumer sovereignty. The American automobile industry provided the motor behind the foreign policy of isolationism.

By 1929, there was one automobile for every five persons in the United States and given the existing structure of the distribution of income, the domestic market seemed to have reached saturation. Production of automobiles in the United States reached a peak in the spring of 1929. The clear leveling off of this massive leading sector was a major factor in the New York stock market crash six months later and in the ensuing Great Depression in the United States. ${ }^{55}$

\section{The foreign export phase and the foreign investment phase}

By analogy with the British pattern of 1873-1896, after the railroads were built, one would expect that one response of the American automobile industry to the saturation of its domestic market would have been to expand its foreign operations, that is, the foreign export and the foreign investment phases of the product cycle. And indeed some of this occurred. The export drive of American automobiles was aborted, however, by tariff walls raised by foreign countries in response to the record-high Smoot-Hawley Tariff, imposed by the United States in 1930 under pressure from the American textile, steel, and other older industries. In regard to foreign investment, Ford had begun manufacturing operations in Britain and Germany in the early 1920s; General Motors had begun manufacturing operations in Germany in 1929. By 1936, of the cars produced in Germany, 40 percent were produced by GM's subsidiary, Opel (the largest automobile producer in Germany), and 10 percent

\footnotetext{
ss Useful accounts of the causes of the Great Depression of 1929-1939 are given in Derek H. Aldcroft, From Versailles to Wall Street, 1919-1929 (Berkeley: University of California Press, 1977); and Charles P. Kindleberger, The World in Depression, 1929-1939 (Berkeley: University of California Press, 1973).
} 
were produced by Ford. But the real era of direct foreign investment by the American automobile industry was to come only after World War II, a war which, among other things, made the world safe for consumer sovereignty.

Europe did not really move into its "auto-industrial age" 36 until after World War II. In 1935, Britain had only one automobile per twenty persons, France one per thirty-five, Germany one per hundred, and Italy one per two-hundred. In contrast the European countries would not reach the U.S. figure of one for every five people until the 1960s. ${ }^{57}$

How were the large amounts of capital for automobile industrialization mobilized in Europe after World War II? One method, analogous to the capital formation for steel and railroads in Britain, France, and Italy decades before, was through the export of manufactured products developed in an earlier stage, i.e., "export-led growth." Here, an important factor was not only the high quality of the products, but the low wages of European labor (relative to the United States) in the two decades after the end of the war. No authoritarian regime was required to repress wages in Europe. The low expectations of union membership, deriving from the privation of World War II, and the political divisions in union organization, deriving from the anti-communism of the Cold War, were for many years the functional equivalent of wage-repression. The role performed in some Latin American countries by their own armies through authoritarian rule, according to the model of Guillermo O'Donnell, was performed in Europe by the ghost of the German Army and the spectre of the Russian Army.

A second method, analogous to the earlier mobilization of capital for railroads in Italy and Spain, was through the import of foreign funds. Until the mid-1950s, this involved U.S. government aid (i.e., the Marshall Plan), and from the mid-1950s until the mid-1970s it involved massive American direct investment in the European automobile industry. Even in the late 1940s, General Motors and Ford owned a large share of the European industry, and in the 1950s the American automobile industry entered into the foreign investment phase of its product cycle on a large scale. The American automobile corporations first undertook large manufacturing investment in Britain, then West Germany, and then France. Normally, when a country of more than 20 million people has reached a certain level of economic development (roughly $\$ 1,000$ per capita GNP in 1965 dollars) it has developed a market in consumer durables which is large and prosperous enough to attract large-scale direct investment in manufacturing by the American automobile corporations. And since European labor was relatively self-restrained in its wage demands, the continued flow of American direct investment also did not require the labor-repressive policies of an authoritarian regime. Of course,

${ }^{36}$ The phrase is from Emma Rothschild, Paradise Lost: The Decline of the Auto-Industrial Age (New York: Random House, 1973).

${ }^{57}$ W. W. Rostow, Politics and the Stages of Growth (Cambridge: Cambridge University Press, 1971), pp. 227-229. 
labor-repressive policies and authoritarian regimes did not inhibit the flow of foreign direct investment in Europe either, as was demonstrated by multinational automobile corporations when they undertook large manufacturing investments in Spain as that country rolled over the $\$ 1,000$ threshold in the late 1960 s.

Although the automobile industries of Britain, West Germany, France, and finally Spain were built up in part with American direct investment, the automobile industry in Italy was built up independently of it. The dominant automobile corporation in Italy, Fiat, had long differed from the other European automobile corporations in that it was a giant and profitable conglomerate which produced locomotives, aircraft, and other machinery, as well as automobiles. Other Italian automobile producers were owned or financed by the state.

Britain, West Germany, France, and Italy finally entered "the autoindustrial age" in the 1950s. The automobile boom of the 1950s-1960s in these countries was at the core of their more general economic prosperity and growth at that time. As many political analysts have observed, this general economic prosperity and growth contributed to the legitimation of the European liberal-democratic systems, to the deradicalization of the European working class, and to the demarxification in the late 1950s of the programs of the British and West German Socialist parties, which had a large working class constituency. The particular features of the automobile boom further contributed to the deradicalization of the European working class by inducing a shift from community activities to individual consumption.

The growth of the automobile industry was especially rapid and pronounced in the ex-Axis countries of Germany and Italy (and also Japan). Not surprisingly, the liberal domestic economic policies of these three countries in the 1950 s and $1960 \mathrm{~s}$, the sort of policies natural to a confident capitalism engaged in a great boom, closely resembled the liberal domestic economic policies of the United States in the 1920s, the time of the first great boom in American automobile production. ${ }^{58}$ In these countries, working class parties did not participate at all in the governments during the 1950s and 1960s, until in West Germany in 1966 recession brought the Socialists into a "Grand Coalition" with the Christian Democrats.

At the time that Europe underwent its postwar automobile boom, the United States also experienced a renewed expansion, a second wind, in its automobile industry, supported in part by the Keynesian fiscal policies of the Federal government, the Federal highway program, and the Federal home mortgage program which encouraged suburbanization.

By the early 1970s, the ratio of cars to persons in Britain, France, West Germany, and Italy had reached about the American level of 1929, just before

\footnotetext{
ss European economic policies in the 1950 s and 1960 s are discussed by Andrew Shonfield, Modern Capitalism: The Changing Balance of Public and Private Power (New York: Oxford University Press, 1969).
} 
the onset of the Great Depression of the 1930s. What happened after these European automobile industries reached the saturation points of their domestic markets? One result contributed to the economic recession and stagnation of 1974-1978. Of course the causes of the economic troubles of the last few years in Europe are many, but the saturation of the automobile market in Britain, France, West Germany, and Italy suggests that there is little basis for a sustained recovery unless, like the French, governments engage in what the Germans have called strukturpolitik, that is, the conscious creation of new leading industrial sectors and the consequent recasting of the nation's industrial structure. A product-cycle theorist would predict that the Europeans would adopt as their new (or renewed) sectors those same industries which were the American new sectors a decade or a generation ago, i.e., aerospace, computers, telecommunications, and nuclear power. And this would explain the intensity of the French export drive in aerospace and the French and German export drive in nuclear power since 1975.

The automobile industries of Spain and Brazil (now ranking about seventh and eighth in size) have developed in a rather different way from those in the United States, Britain, France, West Germany, Italy, and Japan. First, in these six earlier automobile industrializers, at least one large automobile corporation was indigenous to the country; indeed, in the United States, Italy, and Japan, foreign corporations have accounted for almost none of the production. In these earlier industrializers, the concept of the "national champion" against foreign competition has been plausible. In Spain and Brazil, in contrast, there has been no such large indigenous automobile corporation. All large producers are foreign multinationals or closely associated with them.

Second, in Britain, France, and West Germany, the multinational presence has been largely American; in Spain and Brazil, it has been multinational, including various European and Japanese corporations. In the 1960s, corporations such as Leyland, Renault, Volkswagen, Fiat, and Toyota entered into the direct foreign investment phase of their own product cycles.

Third, Spain and Brazil have been the first societies to undertake mass production and consumption of automobiles within an authoritarian political system. But the political consequences of coexistence between the autoindustrial age and an authoritarian regime have been different in the two countries.

In Spain, the multinational automobile corporations pushed the governments after Franco's death in 1975 toward the liberalization and even democratization of the political system. The major reason was that automobiles produced in Spain would be very competitive within the European Common Market if Spain were a member. Spain in the late 1970s could be as cost-effective in automobiles as Italy was in the early 1960s, because Spain today holds roughly the relative wage position that Italy held then. But the Common Market would not admit Spain into membership until, in the words of a resolution passed by each of its main institutions in 1975, "freedom 
and democracy have been established in Spain." (Indeed, given the self-interest of French and Italian farmers, it may not admit Spain even now.)

In Brazil, and in the absence of the special inducements provided by an international organization which is both a common market and a democratic community, the political consequences of the multinational automobile corporations have been in the opposite direction. In the last two years of the Goulart government of the early 1960s, foreign investment in Brazilian manufacturing declined sharply. Among the economic, bureaucratic, and technocratic elites of Brazil, it was a plausible argument that an authoritarian regime was a necessary condition for the renewed flow of foreign investment and $a$ fortiori for the expanding flow which was necessary for the leap into the next stage of industrialization. And, in fact, in the years after the military coup of 1964, American and European investment did pour into Brazil; the output of the automobile industry doubled between 1964 and 1970 and doubled again between 1970 and 1974. However, the foreign investment in the Brazilian automobile industry was somewhat anomalous. Whereas the per capita GNP in other host countries for multinational automobile corporations had been above $\$ 1,000$, the per capita GNP of Brazil in 1966 was only $\$ 340$. This made for a rather thin automobile market, despite Brazil's large population. This "premature" foreign investment in the Brazilian automobile industry was clearly induced by the political stability, repression of labor unions, and low wages which were imposed by the authoritarian regime established after the military coup of 1964 .

Since Brazil had and continues to have a much lower per capita GNP than other large automobile producers, the greatly-increased consumption of automobiles in Brazil required a special form of income redistribution, that is, redistribution to the middle class from the lower classes. This has been accomplished through government measures which repressed working-class real wages, reduced welfare and public health programs, increased middle-class real salaries, and provided government credit for automobile purchases. ${ }^{59}$ These policies, which were necessary for a premature autoindustrial age, could be imposed far more easily by an authoritarian government than by a liberal-democratic one. The calculations of the Brazilian regime were suggested in 1974 by its Finance Minister, Mario Henrique Simsonsen:

A transfer of income from the richest 20 percent to the poorest 80 percent probably would increase the demand for food, but diminish the demand for automobiles. The result of a sudden redistribution would be merely to generate inflation in the food-producing sector and excess capacity in the car industry. ${ }^{60}$

s9 Edmar L. Bacha, "Issues and Evidence on Recent Brazilian Economic Growth" (Cambridge, Massachusetts: Harvard Institute for International Development, Development Discussion Papers, 1976).

${ }^{\circ}$ Quoted in Norman Gall, "The Rise of Brazil," Commentary 63 (January 1977): 49-50. 
When the military sought to legitimize its rule, its principal argument was the success of Brazilian industrialization and the greatly-increased consumption of consumer durables, especially automobiles. Of course, even without the multinational automobile industry, there probably would still have been a military coup in Brazil in 1964 and an authoritarian regime. But the stability of the authoritarian regime was probably due to the course of the automobile industry.

A product-cycle theorist would also have a ready explanation for the U.S. foreign policy of détente with the Soviet Union during the Nixon and Ford Administrations. It was just at the end of the 1960s that the American automobile corporations, which had recently invested heavily in Southern Europe and the more developed parts of Latin America, were searching for the area with the next highest level of economic development, which, of course, was Eastern Europe and the Soviet Union. The SALT I (1972) and Vladivostok (1974) arms agreements were skillfully designed so as to create simultaneously an atmosphere for détente (desired by the American automobile industry and by American international banks) and a ratification of increased production of strategic missiles (desired by the American aerospace industry, which in the late 1960s also entered into a period of economic decline). Thus Henry Kissinger accomplished his own Reinsurance Treaty with the Russians, as Bismarck had done in 1887; at the same time, Kissinger prevented the disruption of the established foreign policy consensus between autos and aerospace, his own "marriage between iron and rye."

Kissinger's achievement was as brilliant as Bismarck's, but it was even more brief. By 1975, the American automobile industry had rediscovered that operations in communist countries usually entailed problems which outweighed the profits. And by 1977, American and European international banks had loaned some $\$ 50$ billion to communist countries, and the banks had perceived that this was about the limit of the countries' capacity for orderly repayment. The American industrial and financial interests supporting détente were now much diminished. It is not surprising that the American political figures supporting détente were too.

At about the same time, the great increase in the world price of oil, as a result of OPEC's actions in what has been called the "October Revolution" of 1973, led Soviet authorities to reduce the growth of the Soviet automobile industry. The "auto-industrial age" of the Soviet Union remains on an ever-receding horizon, and the Soviet ideal remains what it has been since the October Revolution of 1917, a great monument to the leading sectors of the Europe of sixty years ago-steel, chemicals, electricity, and armaments.

\section{Conclusions}

It could be argued that the long era during which leading industrial sectors had an impact upon political outcomes has come to its end. For by now the 
advanced industrial nations are populated with many industrial sectors, and probably never again will one industry alone so dominate these countries as the textile, steel, and automobile industries each did in its time. But our review of the last two centuries also has noted times when political outcomes were shaped not by one sector but by conflicts and coalitions between several, for example, Britain in the 1900s and Germany in the 1920s. The political outcomes of the next decade similarly may be shaped by conflicts between protectionist industries (textiles, steel, recently chemicals) and free trade ones (aerospace, computers, telecommunications), with a swing position being held by the automobile industry, whose interests are divided and conflicting. The long hegemony of the free trade coalition, dating from World War II, may be nearing an end as particular industries and corporations are driven by poor competitiveness in the world market (by phase 4 of Vernon's product cycle), into the protectionist camp. One political consequence would be the eroding of the Atlantic Alliance and of its military organization, NATO, at the very time that the Soviet Union has carried out a large buildup of its military forces in Europe. As the 1890s and the 1930s suggest, a time of protectionist hegemony is unlikely to be an enlightened one.

There is an alternative path and that would be for one country, most probably the United States, to undertake the development of new industrial sectors. Since a new American industry would be likely to create and to dominate for a time an international market for its product, it would be a powerful ally and reinforcement for the now dwindling free trade coalition. And the hegemony of free trade, of "interdependence," might experience a renewal and second wind.

What might be one such new industry in the United States? Here, we might find some clues in the past. Two of our earlier leading sectors, railroads and automobiles, plus another major industry, aerospace, were successive improvements in transportation. ${ }^{61}$ But, as the history of the Concorde suggests, improvements in transportation may have reached the limits possible within the technological frameworks of the old industries. The next logical leap is to move not bodies but minds, i.e., to improve not transportation but communication. This suggests that an obvious candidate for the next great leap forward is the telecommunications industry. It is an even more obvious candidate since the higher cost of petroleum has in part eroded the economic base of the automobile and aerospace industries. And indeed corporations such as IBM, ITT, and RCA are now poised to undertake a number of significant innovations in visual and computer telecommunications. For such innova-

\footnotetext{
'1 I have discussed the American aerospace industry in a number of places, including my "Aerospace Production Lines and American Defense Spending," in American Defense Policy, Richard G. Head and Ervin J. Rokke, editors, third edition (Baltimore: Johns Hopkins University Press, 1973), pp. 626-640; "Why We Buy the Weapons We Do," Foreign Policy 2 (Summer 1973): 33-56; and statement and testimony on American defense production in Defense Industrial Base: DOD Procurement Practices, Hearings before the Joint Committee on Defense Production, Congress of the United States, 95th Congress (Washington: U.S. Government Printing Office, 1977), pp. 63-90.
} 
tions, the main barrier may well be not the lack of capital but the threat of government regulation, which would preserve the sunk investment of the old established corporation in the industry, A.T.\&T. ${ }^{62}$

Will the 1980s see a great telecommunications boom fueling a general economic boom like the great railroad, automobile, and aerospace booms of the past? It is not easy to see the shape of such a development, just as it was not easy to see the shapes of the earlier developments on their eve. But a great telecommunications industrial sector would have implications for military power and international politics as well as for international trade. Today, the liberal democracies of the United States and Western Europe find themselves unable to mobilize the vast financial resources required to match the Soviet Union and its European allies tank-for-tank and plane-for-plane, and unwilling to demoralize themselves through a total dependence upon nuclear weapons. But out of a massive telecommunications industry would issue the inventions and innovations for a new kind of weapons systems and military defense, of which existing "precision-guided munitions," "smart bombs," and "automated battlefields" are only premonitions. And these would be weapons systems in which the technologically-advanced liberal democracies of NATO would have both an absolute and a comparative advantage..$^{63}$ And once again, innovation of new industrial sectors, "gales of creative destruction," would prove to be the basis, and perhaps the necessary condition, for the conservation of old and worthy political institutions.

${ }^{62}$ On the issue of innovation and regulation, see Competition in the Telecommunications Industry, Hearings before the Subcommittee on Communications of the Committee on Interstate and Foreign Commerce, House of Representatives, 94th Congress (Washington: U.S. Government Printing Office, 1977).

${ }^{63}$ On the implications of these new military technologies, see James Digby, Precision-Guided Weapons, Adelphi Papers, no. 118 (London: The International Institute for Strategic Studies, Summer 1975); and Richard Burt, New Weapons Technologies: Debate and Directions, Adelphi Papers, no. 126 (London: The International Institute for Strategic Studies, Summer 1976). 